\title{
ANALISIS TERHADAP PENETAPAN PENGADILAN AGAMA JAKARTA BARAT NO. 28/PDT.P/2017/PA.JB DALAM PENETAPAN DISPENSASI PERKAWINAN ANAK DI BAWAH UMUR DITINJAU DARI UNDANG-UNDANG NOMOR 1 TAHUN 1974 TENTANG PERKAWINAN DAN KOMPILASI HUKUM ISLAM (STUDI KASUS PERKAWINAN ANAK ANTARA MUHAMAD LUKMAN DAN LINA YULIANTI)
}

\author{
Sabrina Agatha Faustina \\ (Mahasiswa Program S1 Fakultas Hukum Universitas Tarumanagara) \\ (E-mail: Sabrina.agathafaustina@yahoo.com)
}

\begin{abstract}
Mulati
(Corresponding Author)

(Dosen Hukum Islam \& Kekeluargaan dan Perkawinan Fakultas Hukum Universitas Tarumanagara, Meraih Sarjana Hukum dari Fakultas Hukum Universitas Tarumanagara, Magister Hukum dari Fakultas Hukum Universitas Tarumanagara)

Abstract

The aim of a marriage according to the Law Number 1 year 1974 is an effort to build a happy and everlasting family based upon the Divinity of Almighty God. The law Number 1 year 1974 contains a principle which explains that both candidates for husband and wife should have already mature in physical and biological, in order to have a good and everlasting marriage without end up in divorce and to obtain a good and healthy offspring thereof. Paragraph 7 Article 1 of the law Number 1 year 1974 stipulated that a man had a right to get marriage if he has been 19 year old and for woman if she has been 16 year old. Even though this time limit of the age herein had been stipulated briefly and clearly, but in the fact it happen frequently that there are still many underage marriage to take place. The court could give a permit to get married and a marriage age dispensation herein through a court decision if he/she had fulfilled a prerequisite procedure and requirement as well. In this point, judge is the main determinant in giving the dispensations.
\end{abstract}

Keywords : Marriage, underage married, judge consideration, dispensation. 


\section{PENDAHULUAN}

\section{A. Latar Belakang}

Perkawinan merupakan salah satu asas pokok hidup yang paling utama dalam pergaulan atau masyarakat yang sempurna. Perkawinan itu bukan saja merupakan satu jalan yang amat mulia untuk mengatur kehidupan berumah tangga dan keturunan, tetapi juga dapat dipandang sebagai salah satu pemenuhan tujuan untuk membentuk keluarga yang bahagia dan kekal berdasarkan Ketuhanan Yang Maha Esa.

Perkawinan merupakan suatu proses yang akan dilalui mayoritas setiap orang dalam menjalani kehidupan. Bagi suatu negara dan bangsa seperti Indonesia adalah mutlak adanya Undang-Undang Perkawinan Nasional yang sekaligus menampung prinsip-prinsip dan memberikan landasan hukum perkawinan yang selama ini menjadi pegangan dan telah berlaku bagi berbagai golongan dalam masyarakat kita. ${ }^{1)}$

Perkawinan di Indonesia diatur dalam Undang-Undang Nomor 1 Tahun 1974 tentang Perkawinan (selanjutnya disebut UU Perkawinan). Undang-Undang tersebut merupakan salah satu unifikasi hukum di Indonesia yang menampung aspirasi masyarakat yang merupakan sumber hukum materil dari perkawinan. Berdasarkan Pasal 1 UU Perkawinan dijelaskan bahwa "Perkawinan adalah ikatan lahir batin antara seorang pria dan seorang wanita sebagai suami istri dengan tujuan membentuk keluarga (rumah tangga) yang bahagia dan kekal berdasarkan Ketuhanan Yang Maha Esa",2, sedangkan pengertian perkawinan menurut Kompilasi Hukum Islam (selanjutnya disebut KHI) yaitu sebagai salah satu ibadah muamalah. Ketentuan Pasal 2 dan 3 KHI menyatakan "Perkawinan adalah pernikahan, yaitu akad yang sangat kuat atau miitsaaqan gholiidhan untuk menaati perintah Allah dan melaksanakannya merupakan ibadah yang bertujuan untuk mewujudkan kehidupan rumah tangga yang sakinah,

\footnotetext{
1) Sudarsono, Hukum Perkawinan Nasional, Cetakan Ke-4, (Jakarta: Rineka Cipta, 2010), hal.6.

${ }^{2)}$ Indonesia, Undang-Undang Nomor 1 Tahun 1974 tentang Perkawinan, Pasal 1.
} 
mawadah dan rahmah."3) Jadi perkawinan menurut agama Islam adalah perikatan antara wali wanita (calon istri) dan calon suami wanita itu, bukan perikatan antara seorang pria dan seorang wanita saja sebagai dimaksud dalam Pasal 1 UU Perkawinan. ${ }^{4)}$

Untuk mewujudkan keluarga tersebut haruslah bersama-sama mengekalkan cinta yang merupakan anugerah dari Allah, karena tidak dapat dipungkiri bahwa kualitas hubungan suami istri dalam rumah tangga sangat mempengaruhi keluarga menjadi sakinah, mawaddah dan rahmah. Sakinah memiliki arti ketenangan. Sakinah terlihat pada kecerahan raut muka yang disertai kelapangan dada, budi bahasa yang halus, yang dilahirkan oleeh ketenangan batin akibat menyatunya pemahaman atau kesucian hati, serta bergabungnya kejelasan pandangan dengan tekad yang kuat. Itulah makna sakinah secara umum dan makna-makna tersebut yang diharapkan dapat menghiasi setiap keluarga yang hendak menyandang Keluarga Sakinah. ${ }^{5}$

Mawaddah mengandung arti rasa cinta. Mawaddah muncul karena di dalam pernikahan ada faktor-faktor yang bisa menumbuhkan perasaan tersebut. Dengan adanya seorang istri, suami dapat merasakan kesenangan dan kenikmatan serta mendapatkan anak dan mendidik serta membesarkan mereka.

Rahmah mengandung arti rasa sayang. Rasa sayang kepada pasangannya merupakan bentuk kesetiaan dan kebahagiaan yang dihasilkannya.

Salah satu syarat dapat terlaksananya suatu perkawinan diatur di dalam Pasal 7 Ayat (1) UU Perkawinan yang menyatakan "Perkawinan hanya diizinkan jika pihak pria sudah mencapai umur 19 (sembilan belas)

${ }^{3)}$ H. Abdurrahman, Kompilasi Hukum Islam di Indonesia, (Jakarta: Akademika Pressindo, 2010), hal.1.

4) Hadikusuma Hilman, Hukum Perkawinan Indonesia, (Bandung: Mandar Maju, 2007), hal.11.

5) Sholeh Gisymar, Kado Cinta Untuk Istri, Cetakan Ke-1, (Yogyakarta: Arina, 2005), hal. 91. 
tahun dan pihak wanita sudah mencapai 16 (enam belas) tahun"6), meskipun telah diatur batasan umur untuk melangsungkan perkawinan pada kenyataannya perkawinan di bawah umur masih sering dilakukan, dalam hal penyimpangan terhadap Pasal 7 Ayat (1) pasal ini dapat meminta dispensasi perkawinan pada pengadilan atau pejabat lain yang ditunjuk oleh kedua orang tua pihak pria ataupun wanita. Dengan kata lain, apabila seseorang ingin melangsungkan perkawinan sementara usianya belum mencapai batas usia tersebut, maka dia harus mengajukan dispensasi perkawinan ke Pengadilan Agama bagi yang beragama Islam dan Pengadilan Negeri bagi yang bukan beragama Islam. Baik pasal tersebut maupun penjelasannya tidak menyebutkan dengan jelas hal apa yang dapat dijadikan dasar bagi suatu alasan yang penting, umpamanya keperluan yang mendesak bagi kepentingan keluarga barulah dapat diberikan dispensasi, karena dengan tidak disebutkannya suatu alasan yang penting itu, maka dengan mudah saja setiap orang bisa mendapatkan dispensasi tersebut. ${ }^{7)}$

Padahal UU Perkawinan kita menganut prinsip di antaranya, bahwa calon suami istri itu harus telah masak jiwa raganya untuk dapat melangsungkan perkawinan, agar dapat mewujudkan tujuan perkawinan secara baik tanpa berakhir pada perceraian dan mendapat keturunan yang baik dan sehat, untuk itu perkwinan di bawah umur seharusnya dicegah. Batasan umur yang terlalu rendah juga akan mengakibatkan laju fertilitas yang sangat tinggi yang dampak buruknya juga terkait dengan pembangunan karena perkawinan juga terkait dengan kependudukan. Dengan pemberian dispensasi perkawinan di bawah umur pembangunan akan menjadi tidak berarti jika pertumbuhan penduduk tidak terkendali, maka peran institusi yang berkompeten menegakkan batasan usia perkawinan tersebut menjadi sangat urgen, karena batas usia yang lebih rendah bagi seorang wanita untuk melangsungkan perkawinan

6) Indonesia, Op.Cit., Pasal 7 Ayat (1). hal.26.

7) K. Wantjik Saleh, Hukum Perkawinan Indonesia, (Jakarta: Ghalia Indonesia, 1980), 
mengakibatkan laju kelahiran yang lebih tinggi, maka dari itu perkawinan di bawah umur seharusnya tidak dapat dilakukan. ${ }^{8)}$

Perkawinan anak atau yang biasanya disebut dengan perkawinan di bawah umur terjadi karena dilatarbelakangi oleh kondisi ekonomi keluarga yang biasanya dijadikan alasan untuk orang tua menikahkan anaknya. Umumnya orang tua yang memiliki banyak anak akan berusaha menikahkan anak perempuannya untuk meringankan beban keluarga dengan tujuan mendapatkan mahar dari pihak pria dengan andil untuk mengamankan masa depan anaknya. Pada beberapa wilayah di Indonesia, ketika kemiskinan benar-benar menjadi permasalahan yang sangat mendesak, perempuan muda sering dikatakan sebagai beban ekonomi keluarga. Oleh karenanya perkawinan dini dianggap sebagai suatu solusi untuk mendapatkan mas kawin dari pihak pria untuk mengganti seluruh biaya hidup yang telah dikeluarkan oleh orang tuanya. Secara sosial ekonomi, perkawinan dini menjadi salah satu gejala yang menunjukkan rendahnya status wanita. ${ }^{9}$

Tentunnya tingkat ekonomi keluarga juga sangat berpengaruh pada tingkat pendidikan anggota keluarga. Rendahnya pendapatan ekonomi keluarga akan memaksa si anak untuk putus sekolah dan tidak melanjutkan pendidikan ke jenjang yang lebih tinggi lagi. Pendidikan merupakan salah satu faktor yang mempengaruhi persepsi seseorang, dengan pendidikan tinggi seseorang akan lebih mudah menerima atau memilih suatu perubahan yang lebih baik. Tingkat pendidikan menggambarkan tingkat kematangan kepribadian seseorang dalam merespon lingkungan yang dapat mempengaruhi wawasan berpikir atau merespon pengetahuan yang ada di sekitarnya. Tinggi rendahnya usia perkawinan dikarenakan rendahnya akses kepada pendidikan, rendahnya

${ }^{8)}$ H. Zain Badjeber, Tanya Jawab Masalah Hukum Perkawinan, (Jakarta: Sinar Harapan, 1985), hal.20-21.

9) Endro Priherdityo, "Pernikahan Usia Anak Masih Marak di Indonesia", https://www.cnnindonesia.com/gaya-hidup/20160723074431-277-146515/pernikahan-usia-anakmasih-marak-di-indonesia, Sabtu, 23 Juli 2016. 
tingkat pendidikan disebabkan oleh ekonomi keluarga yang kurang. Kekurangan biaya menjadi kendala bagi kelanjutan pendidikan. ${ }^{10)}$

Di mana seharusnya masa remaja merupakan masa pencarian jati diri, dan bisa saja dalam proses pencarian jati diri tersebut para remaja memilih jalan yang benar atau yang salah, namun setidaknya melalui proses pencarian jati diri itu mereka akan lebih berhati-hati dalam menuyusun masa depannya. Selain itu adat dan budaya juga merupakan salah satu faktor pendororong terjadinya perkawinan karena di Indonesia masih terdapat adat dan budaya perjodohan di mana anak gadis sejak kecil telah dijodohkan oleh orang tuanya, dan segera dinikahkan sesaat setelah anak menstruasi. Seperti contoh di sebuah pulau yang terletak di Sulawesi Selatan bernama Kodingareng, jika orang tua yang mengetahui anak perempuannya sudah mensturasi maka mereka akan segera mencarikan pasangan untuk dijodohkan dan buru-buru-buru menikahkan anaknya. ${ }^{11)}$

Faktor terakhir yang menjadi pemicu pernikahan di bawah umur terjadi yaitu disebabkan adanya kemauan sendiri dari pasangan. Hal ini disebabkan karena keduanya sudah merasa saling mencintai, maka ada keinginan untuk segera menikah tanpa memandang usia. Adanya perasaan saling cinta dan sudah merasa cocok dalam kondisi remaja yang sudah memiliki pasangan dan pasangannya memiliki keinginan yang sama, yaitu menikah di usia muda tanpa memikirkan problematika rumah tangga untuk ke depannya. Maka mereka pun melaksanakan pernikahannya di usianya yang muda. Praktik dispensasi perkawinan anak bukan hanya terjadi di Indonesia, namun juga terjadi di berbagai negara lain seperti Australia, Brazil, Jerman dan negara-negara lain. ${ }^{12)}$ Pada umumnya, setiap

10) Parastiti Kharisma Putri, "Penyebab Pernikahan Anak Karena Kemiskinan dan Pendidikan Rendah", https://news.detik.com/berita/d-3570366/penyebab-pernikahan-anak-karenakemiskinan-dan-pendidikan-rendah, Minggu, 23 Juli 2017.

${ }^{11)}$ Rizka Diputra, "Lima Daerah di Indonesia Yang Punya Tradisi Nikah Muda", Kamis, 4 Februari 2016.

12) Anonim, "10 Negara Yang Melegalkan Pernikahan Anak di Bawah Umur", http://www.untukku.com/artikel-untukku/10-negara-yang-melegalkan-pernikahan-anak-di-bawahumur-untukku.html. 
negara telah menetapkan batas usia untuk melangsungkan perkawinan atau disebut marriageable age dalam level Undang-Undang.

Untuk mendapatkan dispensasi dari pengadilan pun harus memenuhi syarat sebagaimana diatur dalam Pasal 7 Peraturan Menteri Agama Nomor 11 Tahun 2007 tentang Pencatatan Nikah “Apabila seorang calon mempelai belum mencapai umur 21 (dua puluh satu) tahun, harus mendapat izin tertulis kedua orang tua" untuk menikah. ${ }^{13)}$ Di mana izin ini sifatnya wajib, karena usia itu dipandang masih memerlukan bimbingan dan pengawasan dari orang tua/wali. Setelah izin keluar baru akad nikah bisa dilaksanakan, sehingga izin dijadikan dasar oleh penghulu bahwa kedua mempelai sudah mendapat izin/restu orang tua mereka. Dengan demikian perkawinan yang masih dibawah umur atas izin pengadilan menjadi sah dan berkekuatan hukum tetap.

Dispensasi perkawinan adalah suatu kebijakan yang diberikan oleh Pengadilan Agama kepada calon mempelai yang belum cukup umur untuk melangsungkan perkawinan bagi pria yang belum mencapai usia 19 (sembilan belas) tahun dan wanita yang belum mencapai 16 (enam belas) tahun. Dispensasi perkawinan diajukan oleh orang tua para pemohon baik orang tua pihak laki-laki maupun orang tua pihak wanita kepada Pengadilan Agama atau pejabat lain yang berwenang, pengajuan permohonan dispensasi perkawinan dibuat dalam bentuk permohonan, bukan gugatan.

Menurut Pasal 6 Ayat (1) Peraturan Pemerintah Nomor 9 Tahun 1975 tentang Pelaksanaan UU Perkawinan disebutkan Pegawai Pencatat yang menerima pemberitahuan kehendak melangsungkan perkawinan, meneliti apakah syarat-syarat perkawinan telah dipenuhi dan apakah tidak terdapat halangan perkawinan menurut Undang-undang. ${ }^{14)}$ Menurut Pasal 7 Ayat (2) Peraturan Pemerintah Nomor 9 Tahun 1975 tentang Pelaksanaan UU Perkawinan apabila ternyata dari hasil penelitian terdapat halangan perkawinan sebagai dimaksud Undang-undang dan atau belum

13) Ibid. Pasal 7.

14) Indonesia, Peraturan Pemerintah Republik Indonesia Nomor 9 Tahun 1975 tentang Pelaksanaan Undang-Undang Nomor 1 Tahun 1974 tentang Perkawinan, Pasal 6. 
dipenuhinya persyaratan tersebut dalam Pasal 6 Ayat (2) Peraturan Pemerintah ini, keadaan itu segera diberitahukan kepada calon mempelai atau kepada orang tua atau kepada wakilnya.

Pengadilan berada di posisi yang dilema pada titik ini, di satu sisi pemerintah telah membuat program-program seperti keluarga berencana untuk mencegah angka kelahiran yang tinggi tetapi dengan diberikannya dispensasi perkawinan maka program tersebut seakan-akan kurang terealisasi dengan baik. Di sisi lain pengadilan harus menjaga tujuan Undang-Undang seperti contoh pasangan yang mengajukan permohonan dispensasi perkawinan yang mengalami kehamilan di luar nikah kelak akan melahirkan seorang bayi, jika pengadilan tidak mengabulkan permohonan tersebut maka bayi itu menjadi tidak mendapatkan perlindungan hukum di mana seharusnya ia lahir ke dunia sebagai anak sah yang mempunyai hubungan keperdataan dengan kedua orang tuanya, bukan hanya hubungan keperdataan dengan ibu yang melahirkannya saja. Di sisi lain pengabulan permohonan dengan pemberian dispensasi perkawinan karena terjadi kehamilan di luar perkawinan adalah sebuah tindakan yang dilakukan hakim pengadilan untuk menghindari akibat yang sudah pasti yaitu antara ibu dan bayi yang dikandungnya mempunyai perlindungan hukum karena mengetahui secara jelas siapa ayah dan ibunya.

Di antara perkara permohonan dispensasi perkawinan yang masuk pada Pengadilan Agama Jakarta Barat, penetapan dispensasi perkawinan Nomor: 28/Pdt.P/2017/PA.JB yang akan diangkat menjadi skripsi, karena pada perkara tersebut wanita atau calon istri tidak mengalami kehamilan dan pihak laki-laki belum berusia 19 (sembilan belas) tahun. Alasan yang dikemukakan oleh para pemohon bahwasannya anak pemohon dan calon isterinya sudah saling mencintai dan melakukan hubungan intim sehingga calon suami-istri telah siap dalam membangun keluarga berumah tangga, di samping itu kedua orang tua calon suami-istri sudah sama-sama setuju untuk menikahkan mereka, padahal UU Perkawinan telah mengatur batas usia bagi laki-laki untuk menikah minimal 19 (sembilan belas) tahun. 
Berdasarkan latar belakang di atas maka diangkat skripsi dengan judul: “Analisis terhadap Penetapan Pengadilan Agama Jakarta Barat No. 28/PDT.P/2017/PA.JB Dalam Penetapan Dispensasi Perkawinan Anak di Bawah Umur Ditinjau dari Undang-Undang Nomor 1 Tahun 1974 Tentang Perkawinan dan Kompilasi Hukum Islam (Studi Kasus Perkawinan Anak Antara Muhamad Lukman dan Lina Yulianti)”.

\section{B. Permasalahan}

Berdasarkan uraian latar belakang di atas, maka permaslahan yang hendak dirumuskan adalah:

1. Bagaimana pengaturan penetapan dispensasi perkawinan terhadap anak di bawah umur menurut Undang-Undang yang berlaku di Indonesia?

2. Apakah pertimbangan hakim dalam mengabulkan permohonan dispensasi perkawinan dalam Penetapan Pengadilan Agama Jakarta Barat Nomor 28/Pdt.P/2017/PA.JB sudah sesuai dengan peraturan perundang-undangan yang terkait dengan perkawinan dan mengapa hakim mengabulkan permohonan tersebut?

\section{Metode Penelitian}

Metode penelitian dibutuhkan dalam penulisan skripsi. Metode yang dimaksudkan adalah untuk memberikan data yang seteliti mungkin tentang manusia, keadaan, atau gejala-gejala lainnya.

\section{Tipe Penelitian}

Tipe yang digunakan Penulis dalam penulisan ini yaitu metode penelitian hukum normatif. Menurut Peter Mahmud Marzuki, tidak perlu istilah penelitian hukum normatif, karena istilah legal research selalu normatif. Cukup dikemukakan bahwa penelitian ini adalah penelitian hukum, dengan pernyataan demikian sudah jelas bahwa 
penelitian tersebut bersifat normatife. ${ }^{15)}$ Penelitian hukum dilakukan untuk memecahkan isu hukum yang dihadapi. ${ }^{16)}$ Penelitian hukum (legal research) adalah menemukan kebenaran koherensi, yaitu adakah aturan hukum sesuai dengan prinsip hukum, serta apakah tindakan seseorang sesuai dengan norma hukum atau prinsip hukum.

\section{Jenis dan Sumber Data}

Metode Penelitian normatif terdapat 3 (tiga) macam bahan pustaka yang dapat digunakan, yakin:

a. Bahan Hukum Primer

Bahan hukum primer merupakan bahan hukum yang besifat autoritatif, artinya mempunyai otoritas ${ }^{17)}$ bahan hukum primer yang digunakan dalam penulisan ini adalah Undang-Undang Nomor 1 Tahun 1974 Tentang Perkawinan, Kompilasi Hukum Islam, Peraturan Pemerintah No. 9 Tahun 1975 tentang Pelaksanaan Undang-Undang Nomor 1 Tahun 1974 tentang Perkawinan, Peraturan Menteri Agama Nomor 11 Tahun 2007 tentang Pencatatan Nikah, Undang-Undang Nomor 7 Tahun 1989 yang telah diubah dengan Undang-Undang Nomor 50 Tahun 2009 Tentang Peradilan Agama dan Undang-Undang Nomor 35 Tahun 2014 Tentang Perlindungan Anak.

b. Bahan Hukum Sekunder

Bahan hukum sekunder berupa semua publikasi tentang hukum yang bukan merupakan dokumen-dokumen resmi. ${ }^{18)}$ Bahan hukum sekunder yang digunakan dalam penulisan ini adalah berbagai kepusakaan hukum yakni buku atau jurnal hukum yang berisi

15) Peter Mahmud Marzuki, Penelitian Hukum Edisi Revisi, (Jakarta: Kencana Preneda Media Group, 2013), hal. 56.

${ }^{16)}$ Ibid., hal. 60.

${ }^{17}$ Ibid., hal. 181.

${ }^{18)}$ Ibid., hal 190. 
mengenai prinsip-prinsip dasar (asas hukum), pandangan para ahli hukum (doktrin) berupa semua publikasi tentang hukum.

c. Bahan Non-Hukum

Bahan penulisan yang terdiri atas buku teks bukan hukum yang terkait dengan penelitian, seperti Kamus Besar Bahasa Indonesia dan hasil wawancara.

\section{Pendekatan}

Pendekatan yang digunakan penulis dalam upaya untuk mendapatkan jawaban dari isu yang diteliti adalah pendekatan undang-undang, kasus dan konseptual. Pendekatan Undang-Undang adalah pendekatan yang dilakukan dengan menelaah semua Undang-Undang dan regulasi yang bersangkutan paut dengan isu hukum yang sedang ditangani. ${ }^{19)}$ Pendekatan undang-undang adalah pendekatan yang dilakukan dengan menggunakan legislasi dan regulasi. ${ }^{20)}$ Dalam metode pendekatan undang-undang perlu memahami hierarki, dan asas-asas dalam peraturan perundangan-undangan, dengan menelaah semua Undang-Undang dan regulasi yang bersangkut paut dengan isu hukum yang sedang diteliti. Pendekatan undang-undang dalam penelitian ini mengacu pada peraturan perundang-undangan yang berkaitan dengan batas usia perkawinan dan pertimbangan hakim dalam memberikan dispensasi perkawinan di bawah umur.

Pendekatan kasus adalah pendekatan yang dilakukan dengan cara melakukan telaah terhadap kasus-kasus yang berkaitan dengan isu yang dihadapi yang telah menjadi putusan pengadilan yang telah mempunyai kekuatan hukum tetap. ${ }^{21)}$ Pendekatan konseptual adalah pendekatan yang dilakukan dengan mempelajari pandangan-pandangan dan doktrindoktrin di dalam Ilmu Hukum manakala penulis tidak beranjak dari aturan hukum yang ada.

\section{Teknik Pengumpulan dan Pengolahan Data}

\footnotetext{
${ }^{19)}$ Peter Mahmud Marzuki, Op. Cit., hal. 133.

${ }^{20)}$ Peter, Op.Cit., hal.133-180.

${ }^{21)}$ Ibid., hal.145-180.
} 
Teknik Pengumpulan data yang digunakan dalam penulisan ini adalah dengan studi pustaka terhadap bahan-bahan hukum, baik bahan hukum primer, bahan hukum sekunder dan bahan non-hukum. Penelusuran bahan-bahan hukum tersebut dapat dilakukan dengan membaca, melihat, mendengarkan, maupun melalui media internet. ${ }^{22)}$

Setelah data dan bahan hukum dikumpulkan, tahap selanjutnya adalah melakukan pengolahan data, yaitu mengelola data sedemikian rupa sehingga data dan bahan hukum tersebut tersusun secara runtut dan sistematis. ${ }^{23)}$ Pada penelitian hukum normatif, pengelolaan bahan bertujuan untuk mengadakan sistematis terhadap bahan-bahan hukum tertulis dengan cara melakukan seleksi data sekunder dan bahan hukum, kemudian melakukan klarifikasi menurut penggolongan bahan hukum dan menyusun data hasil penelitian tersebut secara sistematis dan logis.

\section{Tenik Analisa Data}

Hasil pengelolaan data tersebut dianalisis dengan teori yang didapatkan sebelumnya. Teknik analisis data yang digunakan dalam penelitian ini adalah penelitian hukum yang bersifat preskriptif. Penelitian preskriptif, Penulis akan memberikan argumentasi atas hasil yang diperoleh melalui sumber-sumber penelitian. Argumentasi tersebut berupa penilaian mengenai benar atau salahnya, atau apa yang seyogyanya menurut hukum terhadap fakta atau peristiwa hukum dari hasil penelitian.

\section{PEMBAHASAN}

\section{A. Hasil Penelitian}

\section{Profil Kasus dan Para Pihak}

Perkara dispensasi perkawinan di Pengadilan Agama Jakarta Barat termasuk perkara yang sering diajukan, meskipun tidak sebanyak perkara cerai gugat dan cerai talak. Pengadilan Agama Jakarta Barat dalam

${ }^{22)}$ Burhan Ashsofa, Metode Penelitian Hukum, Cetakan ke-5, (Jakarta: Rineka Cipta, 2007), hal.59.

${ }^{23)}$ Peter Mahmud Marzuki, Op. Cit., hal.180. 
memeriksa serta memutus perkara yang berkaitan dengan pemberian dispensasi tentu mempunyai prosedur serta dasar hukum yang sudah menjadi pedoman para hakim dalam menangani kasus ini, dasar hukum ini yang akan menentukan apakah permohonan tersebut akan dikabulkan atau bahkan ditolak, karena belum tentu permohonan yang di ajukan akan di kabulkan, ada juga permohonan yang ditolak karena ada alasan yang kuat berdasarkan Undang-Undang ataupun pertimbangan hakim untuk dikabulkan atau ditolak dalam permohonan dispensasi yang diajukan.

Berikut ini gambaran perkara yang akan dipaparkan dalam penetapan Pengadilan Agama Jakarta Barat Nomor 28/Pdt.P/2017/PA.JB, perkara ini didaftarkan oleh Pemohon yang beragama Islam dan bekerja sebagai karyawan swasta serta bertempat tinggal di daerah Jakarta Barat, mengajukan permohonan dispensasi perkawinan terhadap anak laki-laki pemohon yang bernama Muhamad Lukman yang berumur 18 tahun, beragama Islam dan bekerja sebagai karyawan swasta serta bertempat tinggal di daerah Jakarta Barat dan hendak melangsungkan perkawinan dengan calon isterinya yang bernama Lina Yulianti yang juga beragama Islam, bekerja sebagai karyawan swasta dan bertempat tinggal di daerah Jakarta Barat.

Mengenai duduk perkaranya, dikatakan bahwa anak pemohon ingin menikahi calon isterinya karena sudah kenal lama dan berpacaran sejak beberapa tahun lalu dan sudah saling mencintai sehingga meminta kepada pemohon untuk mengajukan permohonan dispensasi ke Pengadilan Agama agar anak pemohon dapat melangsungkan perkawinan dengan calon istrinya, sedangkan syarat-syarat untuk melangsungkan perkawinan baik menurut ketentuan hukum Islam maupun peraturan perundang-undangan yang berlaku telah terpenuhi kecuali syarat batasan umur untuk melangsungkan perkawinan. Di samping itu, antara keluarga pemohon dan calon isteri anak pemohon ingin segera melangsungkan pekawinan keduanya karena anak pemohon dan calon isterinya diketahui telah berhubungan intim dan hubungan keduanya telah sedemikian erat 
sehingga dikhawatirkan akan terjadi penyimpangan agama yang dilakukan keduanya.

Sehingga pemohon meminta majelis hakim untuk mengabulkan permohonan pengajuan dispensasi perkawinan tersebut dan memberikan izin kepada kedua calon mempelai untuk dapat melangsungkan perkawinan. Berdasarkan Pasal 7 Ayat (1) UU Perkawinan sesuai batas umur yang ditentukan untuk melangsungkan perkawinan, anak pemohon belum mencapai batasan umur yang telah ditetapkan, namun karena Pasal 7 Ayat (2) memungkinkan terjadinya penyimpangan terhadap Ayat (1) maka dalam hal ini dapat meminta dispensasi ke Pengadilan yang berwenang. Dispensasi Perkawinan ialah suatu penyimpangan terhadap batas minimum usia kawin yang telah ditetapkan oleh Undang - Undang dalam bentuk suatu izin atau penetapan. ${ }^{24)}$ Pemberian suatu dispensasi sendiri berada ditangan hakim yang menetapkanya. Batas usia dimaksudkan untuk kematangan fisik, rohani, dan juga sosial agar dapat mengemban tanggung jawab sesuai dengan tujuan perkawinan itu sendiri.

\section{B. Analisis}

\section{Pengaturan penetapan dispensasi perkawinan terhadap anak di} bawah umur menurut Undang-Undang yang berlaku di Indonesia

Pada umumnya aturan-aturan yang berlaku disesuaikan dengan kebutuhan masyarakat, namun seiringnya waktu aturan yang telah lama ada sudah tidak lagi sesuai dengan perkembangan masyarakat karena tidak diperbaharui sedangkan masyarakat dan kebutuhannya terus berkembang. Di dalam pergaulan masa kini, banyak masyarakat yang terkesan mengesampingkan nilai-nilai moral dalam agama serta peraturan-peraturan yang berlaku karena kebebasan yang mereka dapatkan sehingga mereka merasa bebas melakukan apa saja tanpa memikirkan konsekuensinya. Maraknya perkawinan anak menjadi salah satu contoh pergaulan bebas yang terjadi pada zaman sekarang.

24) Sudarsono, Kamus Hukum, Cetakan ke-6, (Jakarta: Rineka Cipta, 2009), hal.102. 
Berdasarkan Pasal 1 UU Perkawinan, pengertian perkawinan adalah ikatan lahir batin antara seorang pria dan seorang wanita sebagai suami istri dengan tujuan membentuk keluarga atau rumah tangga yang bahagia dan kekal berdasarkan Ketuhanan Yang Maha Esa. Ketentuan Pasal 2 dan 3 KHI menyatakan "Perkawinan adalah pernikahan, yaitu akad yang sangat kuat atau miitsaaqan gholiidhan untuk menaati perintah Allah dan melaksanakannya merupakan ibadah yang bertujuan untuk mewujudkan kehidupan rumah tangga yang sakinah, mawadah dan rahmah. Jadi perkawinan menurut agama Islam adalah perikatan antara wali wanita (calon istri) dan calon suami wanita itu, bukan perikatan antara seorang pria dan seorang wanita saja sebagai dimaksud dalam Pasal 1 UU Perkawinan. Salah satu syarat dapat terlaksananya suatu perkawinan yaitu telah mencapai umur atau usia yang telah ditentukan dalam UU Perkawinan. Batasan umur ini dianggap sebagai tanda kesiapan secara fisik dan mental seseorang untuk dapat melangsungkan perkawinan.

Di dalam hukum Islam dan hukum adat tidak mengatur ketentuan khusus mengenai batasan umur seseorang untuk melangsungkan perkawinan. Dalam hukum Islam selama seseorang sudah mengalami akhli baligh maka ia dianggap sudah siap untuk melangsungkan perkawinan. Begitu pula dalam hukum adat, tidak ada ketentuan yang mengatur mengenai batasan umur untuk dapat melangsungkan perkawinan, biasanya dalam hukum adat kedewasaan seseorang diukur dengan tanda-tanda tubuh seperti bagi pria sudah tumbuh jakun atau telah terjadi perubahan suara dan sudah mengalami mimpi basah, sedangkan bagi wanita yaitu sudah haid, buah dada sudah menonjol sehingga ia sudah dikatakan dewasa. Sementara itu dalam Pasal 15 KHI disebutkan bahwa untuk calon suami dan istri diharuskan mengikuti syarat umur sesuai dengan Pasal 7 (1) UU no.1 tahun 1974 ketika melangsungkan suatu perkawinan. Ketentuan yang mengatur tentang dispensasi perkawinan di bawah umur yang berlaku sejak 
disahkannya UU Perkawinan juga diatur di dalam Peraturan Menteri Agama No. 3 Tahun 1975 yaitu:

1. Pasal 12 menitik beratkan kepada dispensasi bagi anak yang belum mencapai umur minimum, yakni:

a. Pernikahan harus didasarkan persetujuan kedua calon mempelai

b. Seseorang calon mempelai yang akan melangsungkan perkawinan belum mencapai umur 21 tahun harus mendapatkan izin sebagaimana yang dimaksud Pasal 6 ayat 2, 3, 4, dan 5 UU Perkawinan

2. Pasal 13 mengatur prosedur pemahaman dispensasi bagi anak yang belum mencapai umur minimum, yaitu:

a. Apabila seorang suami belum mencapai umur 16 tahun, hendak melangsungkan perkawinan harus mendapat dispensasi dari Pengadilan Agama.

b. Permohonan dispensasi perkawinan bagi mereka tersebut pada Ayat (1) pasal ini, diajukan oleh kedua orang tua pria maupun wanita kepada Pengadilan Agama yang mewilayahi tempat tinggalnya.

c. Pengadilan Agama setelah memeriksa dalam persidangan dan berkeyakinan bahwa terdapat hal-hal yang memungkinkan untuk memberikan dispensasi perkawinan dengan sebuah penetapan.

d. Salinan penetapan itu dibuat dan diberikan kepada pemohon untuk melalui persyaratan melangsungkan perkawinan. ${ }^{25)}$

Menurut Bapak Muhammad Abudan selaku Dosen Hukum Islam $^{26)}$, dalam hukum Islam tidak ada ketentuan yang mengatur mengenai dispensasi perkawinan karena dalam hukum Islam perkawinan itu merupakan Sunnah Mu'aqqad yang artinya mendekati wajib, sehingga tidak ada pengaturan khusus juga mengenai batasan umur untuk melangsungkan perkawinan. Dalam hukum islam, selama sudah akhil baligh maka seseorang sudah dapat melangsungkan perkawinan, akhil baligh disini memiliki pengertian pria sudah mengalami mimpi basah dan wanita sudah mengalami mensturasi, dengan kata lain perkawinan anak di bawah umur bukan merupakan suatu perbuatan tercela selama pihak pria memang sudah Mukallaf

\footnotetext{
${ }^{25)}$ Sudarsono, Op.Cit., hal.44-45.

${ }^{26)}$ Penulis, Wawancara dengan Muhammad Abudan, S.H.,M.H., selaku Dosen Hukum Islam di Universitas Tarumanagara, 21 Mei 2018, jam 15.10 s.d 15.40 WIB.
} 
yaitu sudah dewasa dan bisa mempertanggung jawabkan perbuatannya serta Mumayiz yaitu sudah sempurna pemikirannya.

Muhammad Abudan juga mengatakan bahwa UU Perkawinan yang sekarang ini berlaku sudah tertinggal dan tidak dapat mengikuti perkembangan zaman, UU Perkawinan seharusnya diperbaharui agar dapat mengimbangi kebutuhan masyarakat dan bangsa. Seperti pada Pasal 7 UU Perkawinan dinilai seharusnya tidak semua pihak dapat diberikan dispensasi perkawinan, hanya pihak tertentu yang benarbenar dinilai layak untuk melangsungkan perkawinan lah yang diberikan dispensasi dan oleh pihak yang benar-benar mengerti betul tentang persoalan dispensasi serta memahami keseluruhan sifat, watak dan kebutuhan tentang dispensasi perkawinan. Beliau juga mengatakan seharusnya ada penyeragaman pengertian anak karena di dalam aturanaturan yang berlaku seperti UU Perkawinan, Undang-Undang Perlindungan Anak, KUHPerdata batas umur untuk melangsungkan perkawinan berbeda-beda sehingga aturan-aturan tersebut seakan-akan saling tumpang tindih.

Berdasarkan hasil wawancara dengan Rohika Kurniadi Sari, selaku Asisten Deputi Pemenuhan Hak Anak atas Pengasuhan, Keluarga dan Lingkungan. ${ }^{27)}$ Menurut Rohika Kurniadi Sari, dari data yang diperoleh di kementrian, tingkat perkawinan anak di daerahdaerah sangat tinggi sehingga mendorong pemerintah untuk membuat perpu baru karena hal ini dinilai sudah sangat genting, terlebih setelah permasalahan ini didiskusikan kepada Presiden yang kemudian mendukung kementrian untuk segera melanjutkan proses perencanaan pembuatan perpu.

Pasal yang akan disoroti dari UU Perkawinan antara lain Pasal 7 Ayat (1) dan (2) UU Perkawinan karena dalam penjelasan Pasal 7 Ayat (1) UU Perkawinan dijelaskan bahwa untuk menjaga kesehatan suami-

${ }^{27)}$ Penulis, Wawancara dengan Ibu Rohika Kurniadi Sari, selaku Asisten Deputi Pemenuhan Hak Anak atas Pengasuhan, Keluarga dan Lingkungan di Kementrian Pemberdayaan Perempuan dan Perlindungan Anak, 15 Mei 2018, jam 09.00 s.d 10.00 WIB. 
isteri dan keturunan, perlu ditetapkan batas-batas umur untuk perkawinan, namun pada kenyataannya sebelum mencapai umur yang ditentukan dalam UU Perkawinan banyak pasangan yang ingin melangsungkan perkawinan padahal batasan umur yang telah ditentukan dalam UU Perkawinan dinilai sudah relative rendah yaitu 19 (sembilan belas) tahun bagi pria dan 16 (enam belas) tahun bagi wanita sehingga menurut beliau batasan mengenai umur untuk melangsungkan perkawinan harus ditingkatkan lagi untuk mencegah perkawinan anak, sedangkan pada Pasal 7 Ayat (2) dalam hal penyimpangan terhadap ayat (1) pasal ini dapat meminta dispensasi kepada Pengadilan atau Pejabat lain yang ditunjuk oleh kedua orang tua pihak pria maupun pihak wanita, pasal ini dinilai masih sangat rancu terkait syarat permohonan dispensasi dan pihak yang berkewajiban mengajukan permohonan tersebut sehingga kelak syarat mengenai pengajuan permohonan dispensasi akan lebih diperketat dan dibatasi.

Kementerian juga melakukan langkah-langkah untuk mencegah perkawinan anak, antara lain:

a. Kampanye tentang stop perkawinan anak

b. Menandatangani komitmen bersama dengan walikota dan gubernur.

c. Memberikan penghargaan kepada bupati yang tingkat perkawinan anak di daerahnya paling rendah.

d. Melakukan penyuluhan lewat Pusat Pembelajaran Keluarga (Puspaga)

e. Membuat modul fasilitator anak yang dipresentasikan oleh anak remaja.

f. Bermitra dengan Komisi Perlindungan Anak Indonesia

Beliau juga menambahkan bahwa terkait perkawinan anak pihak yang memegang peranan paling penting sebenarnya adalah orang tua 
dan keluarga, dalam Pasal 26 Ayat (1) Undang-Undang Nomor 35 tahun 2014 tentang Perlindungan Anak berbunyi:

Orang tua berkewajiban dan bertanggung jawab untuk:

1) Mengasuh, memelihara, mendidik, dan melindungi anak

2) Menumbuh kembangkan anak sesuai dengan kemampuan, bakat, dan minatnya

3) Mencegah terjadinya perkawinan pada usia anak

4) Memberikan pendidikan karakter dan penanaman nilai budi pekerti pada anak.

Dalam poin 3 Pasal ini secara jelas menyebutkan bahwa orang tua berkewajiban dan bertanggung jawab untuk mencegah terjadinya perkawinan pada usia anak, namun syarat pengajuan permohonan dispensasi perkawinan anak di bawah umur adalah surat izin tertulis dari orang tua dan orang tua lah yang mendaftarkan permohonan tersebut ke pengadilan, maka dapat disimpulkan bahwa kewajiban dan tanggung jawab orang tua dalam hal ini tidak terlaksana dengan tepat sehingga dinilai perlu diadakan penyuluhan-penyuluhan yang lebih terarah kepada orang tua dan keluarga-keluarga agar mereka dapat mengerti betul arti dan manfaar dari perkawinan dan juga dampakdampak dari perkawinan anak.

Pengadilan Agama Jakarta Barat merupakan salah satu pelaksana kekuasaan kehakiman bagi masyarakat yang beragama Islam yang bertugas menyelenggarakan peradilan guna menegakkan hukum dan keadilan berdasarkan pancasila, dengan tugas pokok menerima, memeriksa, dan mengadili serta menyelesaikan setiap perkara yang diajukan kepadanya dan tugas lain yang diberikan berdasarkan peraturan perundang-undangan. Pengadilan Agama Jakarta Barat yang merupakan Pengadilan tingkat pertama bertugas dan berwenang memeriksa, memutus dan menyelesaikan perkara-perkara di tingkat pertama antara orang-orang yang beragama Islam di bidang perkawinan, waris, wasiat, wakaf, hibah, infaq, shadawah dan ekonomi 
syariah sebagaimana diatur di dalam Pasal 49 Undang-Undang Nomor 5 Tahun 2009 tentang Peradilan Agama.

Dalam melaksanakan suatu dispensasi perkawinan terdapat tata cara yang telah diatur oleh Undang-Undang. Dalam hal ini Dispensasi Perkawinan yang telah disebut dalam Pasal 7 Ayat (2) UU Perkawinan memiliki suatu Peraturan Pelaksanaanya yaitu Peraturan Pemerintah Republik Indonesia No. 9 Tahun 1975 Tentang Pelaksanaan UU Perkawinan, didalamnya tidak tertulis mengenai tata cara pengajuan dispensasi perkawinan itu sendiri. Sementara itu bagi yang beragama Islam tertulis peraturan berdasarkan Peraturan Menteri Agama Nomor 3 Tahun 1975 yaitu:

Pasal 12:

(3) Pernikahan harus berdasarkan atas persetujuan kedua calon mempelai.

(4) Seorang calon mempelai yang akan melangsungakn pernikahan belum mencapai umur 21 tahun harus mendapat izin sebagai mana dimaksud Pasal 6 (2), (3), (4), dan (5) Undang - Undang No. 1 Tahun 1974.

Pasal 13:

(5) Apabila seorang calon suami belum mencapai umur 19 tahun dan calon isteri belum mencapai 16 tahun hendak melangsungkan pernikahan harus mendapat dispensasi dari Pengadilan Agama;

(6) Permohonan Dispensasi nikah bagi mereka tersebut pada ayat (1) Pasal ini, diajukan oleh kedua orang tua pria maupun wanita kepada Pengadilan Agama yang mewilayahi tempat tinggalnya;

(7) Pengadilan Agama setelah memeriksa dalam persidangan dan berkeyakinan bahwa terdapat hal - hal yang memungkinkan untuk memberikan dispensasi tersebut, maka Pengadilan Agama memberikan dispensasi nikah dengan suatu penetapan

(8) Salinan penetapan itu dibuat dan diberikan kepada pemohon untuk memenuhi persyaratan melangsungkan pernikahan. 


\section{Pertimbangan Hakim}

Setelah melakukan wawancara dengan hakim yang menangani perkara penetapan Nomor 28/Pdt.P/2017/PA.JB, hakim mengabulkan permohonan tersebut karena hakim menilai antara anak pemohon dengan calon isterinya sudah saling mencintai dan keduanya sudah bekerja, hakim memiliki tugas untuk menetapkan berdasarkan keyakinannya, sehingga dalam hal ini setelah melihat langsung keadaan fisik anak pemohon maka hakim telah berkeyakinan anak pemohon tersebut telah siap untuk menjadi seorang suami. Pertimbangan hakim disini bersifat berdasarkan pengetahuanya sebagai seorang hakim.

Hakim tidak hanya berpacu pada Undang-Undang karena apabila hakim menggunakan pendekatan metodologi dalam pengkajian hukum Islam (figh) mengenai permohonan usia perkawinan, perlu dipertimbangkan mushalat mursalah (metode ijtihad dalam hukum Islam yang berdasarkan kemashlatan umum). ${ }^{28)}$

Jika merujuk dalam Hukum Islam maka, dalam Hukum Perkawinan Islam disebutkan bahwa tidak ada syarat umur bagi pria, selain baligh dan berakal dengan demikian dapat dilihat anak pemohon telah baligh dan juga telah sadar tugasnya untuk menjadi seorang suami. Di sisi lain kedua keluarganya sudah menyetujui dan ingin segera melangsungkan perkawinan tersebut agar tidak melanggar ketentuan dalam agam Islam, sehingga hakim merasa tidak mempunyai alasan untuk menolak permohonan ini.

\section{PENUTUP}

\section{A. Kesimpulan}

Pada artikel ini maka penulis dapat mengemukakan kesimpulan yang di dapat dari permasalahan yang terdapat dalam skripsi yang berjudul "Analisis Terhadap Penetapan Pengadilan Agama Jakarta Barat No.

\footnotetext{
${ }^{28)}$ Zainuddin Ali, Hukum Perdata Islam di Indonesia, (Jakarta: Sinar Grafika, 2006), hal.14.
} 
28/Pdt.P/2017/PA.JB Dalam Penetapan Dispensasi Perkawinan Anak di Bawah Umur ditinjau dari Undang-Undang No. 1 Tahun 1974 tentang Perkawinan dan Kompilasi Hukum Islam (Studi Kasus Perkawinan Anak Antara Muhamad Lukman dan Lina Yulianti)". Dalam hal ini penulis dapat mengambil kesimpulan sebagai berikut:

1. Dispensasi Perkawinan yang diatur dalam Pasal 7 Ayat (2) UU Perkawinan yang mengesampingkan syarat umur perkawinan dalam Pasal 7 Ayat (1) UU Perkawinan 1974. Disebutkan dalam Pasal 7 Ayat (2) bahwa untuk melangsungkan perkawinan tanpa mengikuti syarat umur tersebut maka dapat meminta dispensasi kepada Pengadilan atau Pejabat lain yang ditunjuk oleh kepada kedua orang tua pihak pria maupun wanita. Pemberian suatu dispensasi berada ditangan hakim yang menetapkanya dimana harus adanya permohonan dari orang tua. Hakim menetapkan sesuai dengan pengetahuan dan keyakinanya, apakah suatu dispensasi layak diberikan atau tidak. Penilaian yang dilakukan hakim bersifat selektif, tidak semua permohonan dispensasi dikabulkan, hal tersebut berdasarkan kepatutan dan juga ketertiban umum.

2. Dalam Penetapan Pengadilan Agama Nomor 28/Pdt.P/2017/PA.JB Hakim memberikan dispensasi kepada anak laki - laki pemohon yang berumur 18 tahun untuk melangsungkan perkawinan. Hakim melihat adanya perkawinan yang perlu diselenggerakan karena kegigihan anak pemohon dan calon istri anak pemohon yang menyatakan saling mencintai dan telah berhubungan intim sehingga ditakutkan terjadi penyimpangan ketentuan agama. Selain itu dalam pembuktianya hakim melihat bahwa anak pemohon tersebut dinilai siap untuk melangsungkan perkawinan karena sudah bekerja. Dengan demikian maka hakim berkeyakinan untuk memberikan dispensasi perkawinanan sesuai dengan Pasal 7 (2) UU No.1 Tahun 1974 Tentang Perkawinan. 


\section{B. Saran}

Dari kesimpulan yang telah ditulis oleh penulis, maka dalam kesempatan kali ini penulis ingin memberikan saran dalam penyelesaian permasalahan ini sebagai berikut:

1. Dispensasi perkawinan memang diatur dalam Pasal 7 Ayat (2) UU Perkawinan, tetapi seharusnya penggunaanya harus dibatasi dan syarat-syarat pengajuannya diperketat. Dispensasi merupakan suatu penyimpangan dari batas umur perkawinan agar diperbolehkan untuk melangsungkan perkawinan, sehingga pemberian dispensasi perkawinan untuk perkawinan anak di bawah umur diharapkan menjadi hal yang darurat dan dihindari.

2. Dalam menetapkan pemberian dispensasi maka hakim harus menetapkan berdasarkan keyakinannya dan pengetahuanya, serta benar-benar mencari celah untuk tidak memberikan dispensasi tersebut apabila terbukti salah satu pihak tidak cukup siap untuk melangsungkan perkawinan, dan hakim harus memberikan dispensasi secara patut dan sesuai dengan ketertiban umum agar perkawinan tersebut berjalan sesuai dengan tujuanya.

3. Pemerintah dalam melakukan penyuluhan-penyuluhan hukum mengenai tujuan perkawinan hendaknya ditingkatkan kembali agar masyarakat sadar akan akibat-akibat negtaif yang timbul dari pelaksanaan perkawinan anak di bawah umur dan diharapkan mereka mengesampingkan dulu adat istiadat dan kepercayaan yang berlaku di daerah tempat tinggal mereka.

4. UU Perkawinan yang sudah berlaku sejak tahun 1974 seharusnya diperbaharui sesuai dengan kebutuhan masyarakat sekarang. Pemerintah sebaiknya memperhatian dampak-dampak biologis bagi anak-anak sebagai pertimbangan utama dalam mengkaji ulang UU Perkawinan, di samping dapat membantu mencegah angka kematian 
ibu dan anak yang cukup tinggi di Indonesia juga diharapkan dapat mencegah angka kelahiran yang tinggi dan menghasilkan anak-anak yang lebih berkualitas.

5. Dengan adanya pengakjian ulang untuk merivisi UU Perkawinan seharusnya dibuat penyeragaman pengertian anak, dispensai serta kategori ukuran kedewasaan sehingga hal ini akan mempermudah hakim dalam memutus suatu perkara, dan hakim dapat berpegang teguh pada aturan-aturan yang berlaku tanpa harus berada dalam dilemma karena juga harus memperhatikan faktor-faktor lain di luar Undang-Undang.

\section{DAFTAR PUSTAKA}

\section{A. Buku}

Abdurrahman, H. Kompilasi Hukum Islam di Indonesia. Jakarta: Akademika Pressindo, 2010

Ali, Zainuddin. Hukum Perdata Islam di Indonesia. Jakarta: Sinar Grafika, 2006

Ashsofa, Burhan. Metode Penelitian Hukum. Cetakan ke-5. Jakarta: Rineka Cipta, 2007

Badjeber, H. Zain. Tanya Jawab Masalah Hukum Perkawinan. Jakarta: Sinar Harapan, 1985

Gisymar, Sholeh. Kado Cinta Untuk Istri, Cetakan Ke-1. Yogyakarta: Arina, 2005

Hilman, Hadikusuma. Hukum Perkawinan Indonesia. Bandung: Mandar Maju, 2007

Mahmud Marzuki, Peter. Penelitian Hukum. Jakarta: Kencana Preneda Media Group, 2013

Saleh, Wantjik. K. Hukum Perkawinan Indonesia. Jakarta: Ghalia Indonesia, 1980

Sudarsono, Hukum Perkawinan Nasional. Jakarta: Rineka Cipta, 1991 , Kamus Hukum. Cetakan ke-6. Jakarta: Rineka Cipta, 2009 


\section{B. Peraturan Perundang-undangan}

Indonesia. Instruksi Presiden Republik Indonesia Nomor 1 Tahun 1991 tentang Komplilasi Hukum Islam.

. Undang-Undang Nomor 1 Tahun 1974 tentang Perkawinan (Lembaran Negara Republik Indonesia Tahun 1974 Nomor 1 dan Tambahan Lembaran Negara Republik Indonesia Nomor 3019)

- Undang-Undang Nomor 7 Tahun 1989 tentang Peradilan Agama (Lembaran Negara Repunlik Indonesia Tahun 1989 Nomor 49 dan Tambahan Lembaran Negara Nomor 3400)

- Undang-Undang Nomor 5 Tahun 2009 tentang Perubahan Kedua Atas Undang-Undang Nomor 7 Tahun 1989 tentang Peradilan Agama (Lembaran Negara Republik Indonesia Tahun 2009 Nomor 159 dan Tambahan Lembaran Negara Republik Indonesia Nomor 5078)

Undang-Undang Nomor 35 Tahun 2014 Tentang Perlindungan Anak (Lembaran Negara Republik Indonesia Tahun 2014 Nomor 297 dan Tambahan Lembaran Negara Nomor 5606)

, Peraturan Menteri Agama Nomor 11 Tahun 2007 Tentang Pencatatan Nikah.

\section{Internet}

Anonim. "10 Negara Yang Melegalkan Pernikahan Anak di Bawah Umur", http://www.untukku.com/artikel-untukku/10-negara-yangmelegalkan-pernikahan-anak-di-bawah-umur-untukku.html, diakses 10 Maret 2018.

Endro, Priherdityo. "Pernikahan Usia Anak Masih Marak di Indonesia", https://www.cnnindonesia.com/gaya-hidup/20160723074431-277146515/pernikahan-usia-anak-masih-marak-di-indonesia, diakses 2 Januari 2017.

Parastiti, Kharisma Putri. "Penyebab Pernikahan Anak Karena Kemiskinan dan Pendidikan Rendah", dalam https://news.detik.com/berita/d-3570366/penyebab-pernikahananak-karena-kemiskinan-dan pendidikan-rendah, diakses 10 Maret 2018 .

Rizka, Diputra. "Lima Daerah di Indonesia Yang Punya Tradisi Nikah Muda", https://news.okezone.com/read/2016/02/04/340/1305079/lima- 
daerah-di-indonesia-yang-punya-tradisi-nikah-muda, diakses 10 Maret 2018

D. Kasus

Penetapan Pengadilan Agama Jakarta Barat Nomor 28/Pdt.P/2017/PA.JB 